\title{
INTERAKTIVITA A INSCENOVANÉ SVETY (s dôrazom na otázky simulácie a inscenácie vo videohrách)
}

\author{
JURAJ BÚRY \\ Ústav literárnej a umeleckej komunikácie, \\ Filozofická fakulta Univerzity Konštantína Filozofa v Nitre
}

\begin{abstract}
Abstrakt: Text implicitne porovnáva princípy inscenácie, hlavne divadelnej, s princípmi, akými sa vytvára naratívny konflikt vo videohrách. Explicitne sa zameriava na simulačné procesy videohier. Robí tak cez optiku dvoch prístupov k videohernej teórii. Prvým je aspekt odborného diskurzu, v ktorom autor využíva už zavedenú odbornú terminológiu z divadelnej teórie a snaží sa identifikovat’ aspekty videohier, ktoré s ňou korešpondujú. Pritom vytvára tézu, že existujú dva základné videoherné princípy - kompetitívnost’ a interaktívne rozprávanie. Tieto princípy stavia do opozície, pričom sa zameriava na druhý z nich. Inscenáciu v texte teda chápe ako druh simulácie a argumentuje, prečo sa tento princíp stvárňovania príbehov objavuje aj vo videohrách. Druhý princíp uvažovania o videohrách je uvažovaním z pozície hráčov. V tomto kontexte autor hladá argumenty pre potvrdenie jeho tézy. V nestálej terminológií videohier odkrýva základné uvažovanie stavajúce do opozície sútažné hranie a rolové hranie. V závere popisuje vztah inscenácie a simulácie $\mathrm{v}$ kontexte videohier ako naratívneho média.
\end{abstract}

Kl'účové slová: videohry, inscenácia, simulácia, naratív, interakcia, kompetitívnost', interaktívna fikcia, hry, inscenovanie

Hry sú pevnou súčastoou kultúry a civilizácie. Každodennou realitou sa stala aj ich najnovšia, elektronická forma - videohry. Reakcie na tento fenomén nachádzame tiež v umeleckej sfére, najmä vo výtvarnom umení. ${ }^{1}$ Súčasne sa formuje odborná reflexia videohier, ktorá sa skladá z dvoch hlavných prúdov. Prvým je ustálený akademický diskurz humanitných a kultúrnych vied, ktoré sa snažia reagovat’ na narastajúci fenomén a vysvetlit ho v už zostavených a existujúcich teóriách pomocou existujúcich štruktúr, slovníkov a referenčných rámcov. Tento prístup sa javí ako sčasti problematický, lebo existujúce pojmy nie vždy dokážu plnohodnotne popísat' vlastnosti či systém videohier. Ak teda chceme čokol'vek vypovedat’ o videohrách a ich vzt’ahu $\mathrm{s}$ ktorýmkol'vek z tradičných umení, treba vymedzit’ vlastnosti videohier a tiež to, ktoré z nich spadajú do sféry nášho záujmu. Ciel’om tohto textu nie je vytvorit’ nový systém členenia videohier. Jeho ambíciou je skôr poskytnút klúč k triedeniu videohier na tie, ktoré využívajú primárne druh komunikácie typickej aj pre iné naratívne formy (pričom predpokladáme, že práve táto skupina videohier bude obsahovat' znaky spoločné s divadlom), a na tie, ktoré tento spôsob komunikácie nevyužívajú. Nie všetky videohry totiž pracujú s naratívnymi postupmi, umeleckými jazykmi a rozprávačskými prvkami.

\footnotetext{
${ }^{1}$ Ako referencia tohto tvrdenia môže poslúžit publikácia zostavená Chrisom Melissinosom a Patrickom O Rourkom. Pozri MELISSINOS, Ch. - O'ROURKE, P. The Art of Video Games. New York : Rizzoli US, 2012.
} 
Teoretické myslenie o videohrách je v našom jazykovom priestore pomerne mladé. ${ }^{2} \mathrm{~V}$ kontextoch Nitrianskej školy do neho čiastkovo prispela estetička Michaela Malíčková v publikácií Hra(nie) len ako estetický fenomén. ${ }^{3}$ Zameriava sa na reprezentácie herných princípov v už ustálenom estetickom systéme filmu, pričom najskôr tematizuje teóriu hier. Jej práca sa nevzţahuje výlučne na videohry, ale na hry všeobecne. Využíva pri tom už existujúce teórie a klasifikácie hier od Friedricha Nietzscheho, Rogera Cailloisa, Eugena Finka, Johana Huizingu a iných autorov. Zároveň ich estetiku odvodzuje od princípu vonkajších podobností, s ktorým pracuje pri svojich umenovedných teóriách aj Morris Weitz. ${ }^{5}$ Malíčková vd’aka tomu vytvára synkretickú definíciu hier a herného princípu, ked’ tvrdí: „Hru by sme mohli charakterizovat ako špecifický druh dobrovol'nej činnosti, ktorá sa oproti skutočnosti vymedzuje osobitným priestorom, časom a pravidlami. Herný princíp operuje v perspektíve akoby, produkuje teda istý svet zdania, ktorý je napriek svojej fiktívnosti schopný udržiavat' významovú súvislost' s realitou. “6 Ďalej píše: „Hra nadobúda skutočný význam, ked” sa deje, odohráva, ked’ prebieha, je hraná, teda napĺn̆a svoj procesuálny charakter. ${ }^{\text {"7 }}$ Upozorňuje pritom, že procesuálnost’ hry je formou aktívneho dialógu medzi hráčom a hrou.

Ked’že Malíčkovej definíciu je možné aplikovat’ aj na videohry, využijeme ju pri vymedzení artefaktov, ktorých sa naša teória dotýka. Treba však upozornit na to, že videohry sú špecifickým druhom hier, ktorý má oproti ostatným hrám vlastné vnútorné systémy a špecifiká. Základný rozdiel je zaznamenaný už v pojme videohry. Práve čast’ slovnej zloženiny „video“ určuje základný charakter týchto hier - sú totiž hráčovi sprostredkované prostredníctvom audiovizuálnej techniky, najmä prostredníctvom monitoru, pričom ku komunikácii dochádza vd’aka technickým extenziám - ovládačom. Ovládače v tomto prípade slúžia nielen ako extenzia samotnej hry, ale zároveň určujú spôsob, akým sa hráč sprítomňuje v hre. Tvoria komunikačný most zabezpečujúci dialogický proces hrania. Priestor, v ktorom sa videohry odohrávajú, je virtuálny a je nutné, aby bol týmto spôsobom reprezentovaný v našej ontologickej realite. Naproti tomu, iné formy hier sú vždy prítomné v realite. $Z$ definície Michaely Malíčkovej sa dá tiež usudzovat', že hry sú formou simulácie. Simulácia je spôsob napodobňovania procesu či interakcie s nejakým predmetom. Výpočtový charakter počítačovej techniky umožňuje tvorbu rozsiahlych simulácií, pri ktorých sa hráč môže sústredit na iné aspekty hrania. Výsledky rôznych simulovaných procesov za neho sleduje samotná hra. Pri tradičnejšom hraní musí tieto procesy sledovat' hráč, prípadne nezaujatý pozorovatel' (rozhodca).

\footnotetext{
${ }^{2}$ Máme na mysli priestor českých a slovenských vedeckých pracovísk.

${ }^{3}$ MALÍČKOVÁ, M. Hra(nie) len ako estetický fenomén. Nitra : Univerzita Konštantína Filozofa, Filozofická fakulta, Ústav literárnej a umeleckej komunikácie, 2008.

${ }^{4}$ Teórie spomenutých autorov sa však týkajú najmä hier prítomných v našej ontologickej realite (stolné hry, hry v priestore, detské hry a pod.), prípadne obšírnejších herných princípov, ktoré síce môžu pomôct’ formovat aj základy teórie videohier, ale pre účely nášho textu nie sú podstatné, ked’že nepostačujú k tomu, aby postihli komplexnost' videohier. Napríklad Cailosove štyri základné ciele hier by sa vo videohrách vol'ne kombinovali, pričom by sa mohli vyskytovat’ aj všetky štyri naraz, čím sa stráca zmysel ich identifikácie a delenia. Navyše v tomto texte nesledujeme delenie hier ako také, ale podobnost’ videohier s divadlom.

${ }^{5}$ Malíčková aj Witz sa opierajú o prácu Ludwiga Wittgensteina Philosophical Investigations (2009).

${ }^{6}$ MALÍČKOVÁ, M. Hra(nie) len ako estetický fenomén, s. 49.

${ }^{7}$ Tamže.
} 
Videohry vznikli ako experimentálne simulácie, ktoré mali za úlohu demonštrovat výpočtové a technické možnosti prvých počítačov, no rýchlo sa z nich stalo samostatné odvetvie. Stále sú závislé na technologickom pokroku, vyvíjajú sa spolu s ním, niekedy dokonca vývin počítačovej techniky iniciujú. ${ }^{8}$ Práve rozsiahle možnosti simulovania priniesli do hier aj iný aspekt.

Prvé videohry sa zameriavali hlavne na jednoduché konfliktné procesy, ktoré modelovali formu hrania „proti niečomu/niekomu“. Jedny z prvých hier mali formu piškvoriek $^{9}$ či vesmírneho letu. Pri tomto modeli hrania je dôležité mat’ protihráča, ktorého zastupuje iný hráč alebo hra samotná. Tento model je vo videohrách prítomný dodnes, hry sa stávajú sútažnými (čo je pojem, ktorý je najvhodnejší na ich označenie). Môžeme k nim radit Tetris, Pac-mana, populárne súbojové hry ako Mortal Combat, tímové hry ako DOTA 2 či vesmírnu stratégiu StarCraft ${ }^{10}$. Estetický (audiovizuálny) rozmer týchto hier je druhoradý, slúži len na to, aby sa hráč v simulácií orientoval.

S rozšírenými možnostami sa začali objavovat̉ i videohry, ktoré sa zameriavali na estetický, umelecký a naratívny potenciál videoherného média. Práve tento typ hier „na niečo “11 je najčastejším objektom humanitných vied a umenovedného uvažovania o hrách. Slovníkový aparát si toto uvažovanie požičiava zo systémov tradičnejších umeleckých foriem, najmä filmu, literatúry, výtvarného umenia alebo divadla. Tento prístup sa opiera o vonkajšie podobnosti hier s umeleckými druhmi. Prvé hry pracujúce s príbehovým naratívom a umeleckým jazykom čerpali hlavne z literatúry. Obsahovali aj výtvarnú a audiovizuálnu stránku, tá však bola doplnená textom. Najvýraznejšie to bolo pri tzv. textových adventúrach. Príkladom takejto hry je Zork z roku 1980. Hráčovi sa v okne zjavil text popisujúci okolie. On zadal do programu príkaz v podobe jednoduchej vety ${ }^{12}$, na čo hra reagovala výpisom d’alšieho textu, ktorý popisoval, ako prostredie interaguje na hráčove akcie. Dialogická forma hrania fungovala v podstate ako interaktívny román, ktorého protagonistom bol hráč. Takéto videohry sa nazývajú textové adventúry.

Nielen tento druh videohier preberal literárne prvky. Pri textových adventúrach išlo aj o literárne prevedenie, ale iné a neskoršie hry, ktoré prezentovali nejaký typ príbehového naratívu, pracovali s pravidlami dramatickej výstavby textu, postáv a charakterov. S pribúdajúcimi možnostami (lepšia grafika, vyšší výkon výpočtovej techniky) začali využívat’ aj prístupy používané vo výtvarnom umení (pixelové vykreslenie fungujúce na rovnakom princípe ako pointilizmus, výtvarná abstrakcia a pod.) či filme. Pribudla práca s kamerou, strihovou skladbou a zvukom, pričom zvyčajne išlo o vsuvky, tzv. cut scenes, vložené medzi jednotlivé levely alebo časti hry. V súčasnosti sa však videohry natol'ko vyvinuli, že aj herné časti bývajú doplnené o dabing realizovaný profesionálnymi hercami, alebo animácie postáv sú vytvore-

\footnotetext{
${ }^{8}$ Lepšia technika dokáže vytvárat' zložitejšie a dôveryhodnejšie simulácie. Hardvérové spoločnosti vyvíjajú novú techniku práve pre potrebu týchto simulácií, pričom videohry sú ich najrozšírenejšou formou. Pri bežnej práci, napr. v kanceláriách, nie je nevyhnutná silná výpočtová technika.

${ }^{9}$ OXO, vytvorená Alexandrom S. Douglasom v roku 1952.

${ }^{10}$ Mohli by sme namietat', že napríklad StarCraft obsahuje aj príbehovú kampaň pre jedného hráča. Popularita hry však nespočíva v tomto aspekte, ale najmä v jej kompetitívnej časti, v ktorej hrajú hráči proti hráčom. StarCraft bol dlhé roky hlavným predstavitel’om tzv. elektronických športov.

${ }^{11}$ Napríklad na detektíva, na lovca príšer, vesmírneho dobrodruha, rytiera a podobne.

12 Napríklad: „Open door.“ "Go north.“"
} 
né pomocou techniky motion capture ${ }^{13}$. Na tvorbe videohier sa tak podielajú skutoční herci a vzniká priestor pre dramatické inscenovanie. Práve toto je jedna z prvých analógií medzi videohrami a divadlom.

V súčasnosti, hlavne vo videohernom žánri adventúr a RPG hier ${ }^{14}$, je kladený vel'ký dôraz na príbeh a estetické prevedenie hry. Ako príklad môže poslúžit hra Life is Strange od Dotnod Entertaiment, publikovaná v roku 2015. Ide o adventúru, v ktorej sa hráč vžíva do postavy tínedžerky Max Caufield. Max nastupuje na novú, umeleckú strednú školu, kde narazí na kamarátku z detstva Cloe. Spolu sa rozhodnú vypátrat' ich nezvestnú spolužiačku, pričom Max odhaluje, že má schopnost̉ manipulovat' časom. Podstata hry tkvie v tom, že hráč prostredníctvom Max preskúmava jednotlivé lokality príbehu a vedie rozhovory s ostatnými charaktermi. Na základe zistených informácií sa potom v klúčových momentoch hry alebo v dialógoch snaží vyskladat' celý obraz diania a rozhodnút', ako budú Max a Cloe d’alej postupovat'. Schopnost' obracat čas dáva hráčovi priestor preskúmat’ väčšinu možností, ale vždy si musí zvolit’ len jednu, čím sám buduje príbeh. Dvaja rôzni l’udia, respektíve dve rôzne hrania hry môžu priniest' dva rozdielne príbehy. Life is Strange v tomto prípade funguje skôr ako interaktívny film využívajúci estetické postupy filmového rozprávania. Samotné hranie nepripomína simuláciu, ale skôr naratívne laboratórium, v ktorom hráč preskúmava emočne zložité dramatické konflikty. Potešenie z hrania nie je postavené na porážaní súperov, ale na odhal'ovaní záhady, rozpletaní a budovaní dramatického konfliktu. Skôr než simulovanie tak hra pripomína interaktívnu inscenáciu. Dalo by sa povedat', že videohra inscenuje dramatické konflikty pre potešenie hráča.

Teatrológovia Peter Oravec a Dagmar Inštitorisová popisujú inscenovanost’ ako „spôsob komponovania divadelného tvaru (situácie, akcie atd'.) prostredníctvom divadelných výrazových prostriedkov. Pojem sa nevztahuje iba na divadelné umenie, divadelné inscenačné postupy využívajú aj iné druhy umenia a nachádzame ich aj v bežnom živote. "15 Inscenovanie je podl'a nich využívanie divadelných postupov (teatrálnost', maska, hranie rol), ktoré sa odohráva v určitom prostredí (scéne) a v istom čase, $\mathrm{v}$ ktorom prebieha priamy kontakt s recipientom inscenovaného artefaktu: „Pod inscenovaním rozumieme spôsob tvorby divadelného diela podla vopred známej a dohodnutej koncepcie, ked’ sa realizuje základná vizuálno-akustická predstava o výslednom tvare. Ide o jej významové komponovanie vo zvolenom priestore so zvolenými divadelnými výrazovými prostriedkami. Inscenovanie teda vždy obsahuje všetky divadelné umelecké postupy - aj režijné, herecké, výtvarné, dramatické, hudobné, a artefakty umeleckých činností, ktorým prináležia (réžia, herectvo, scénografia, dramaturgia, scénická hudba atd..)“16

Umelecký jazyk tohto typu videohier pracuje skôr s výrazovými prostriedkami filmu než divadla, a to pre samotný spôsob reprezentácie videohier - vizualizácii cez monitory. Vizuálna stránka súčasných hier teda naplno pracuje s jazykom filmu,

${ }^{13}$ Filmárska technika zachytávajúca pohyby skutočných hercov, ktoré sú v počítači prepojené s animovanými modelmi.

${ }_{14}$ Role-playing games. Pôvodne išlo o druh stolnej hry, pri ktorej sa od hráča vyžadovalo hrat' ním zvolenú rolu dobrodruha.

${ }^{15}$ INŠTITORISOVÁ, D. - ORAVEC, P. Inscenovanost'. In INŠTITORISOVÁ, D. a kol. Divadlo interaktivita, inscenovanost,', diškurz. Nitra : Univerzita Konštantína Filozofa, Filozofická fakulta, Ústav literárnej a umeleckej komunikácie, 2013, s. 445.

${ }^{16}$ Tamže. 
avšak druh komunikácie, ktorý prebieha medzi hráčom a hrou, pripomína skôr komunikáciu medzi divákom a divadelným predstavením. Hráč slúži nielen ako divák, ale aj ako aktívny činitel', bez vkladu ktorého by sa hra nerealizovala. Ako sa divadlo realizuje pri konkrétnom inscenovaní na konkrétnom mieste a v konkrétnom čase, tak sa videohry odohrávajú v konkrétnom, vopred komunikovanom virtuálnom prostredí. Sú prezentované vizuálno-akustickou formou a neuskutočnia sa bez toho, aby boli objektom aktívnej recepcie hráča. ${ }^{17} \mathrm{Na}$ vykreslenie dramatického konfliktu sú použité režijné, herecké, scénické, výtvarné a hudobné prostriedky. Interakcia hráča s hrou sa vyznačuje využívaním postupov improvizácie. ${ }^{18}$ Hráč nemusí dopredu poznat’ všetky impulzy, ktoré mu videohra poskytne, avšak musí na ne v reálnom čase reagovat'. $\mathrm{V}$ tomto prípade nejde o inscenáciu $\mathrm{v}$ pravom, divadelnom význame, ale o jej virtuálnu variáciu. Prítomný je tu hlavne inscenačný proces, ktorý je zosobnením aktívnej komunikácie medzi hráčom a videohrou. Stále ostáva zachovaný procesuálny charakter simulácie, ale s naratívnou a dramatickou nadstavbou sa tento proces transformuje na inscenovanie dramatických situácií.

Podobnost' s divadlom vykazujú videohry s naratívnym aspektom aj v d’alšej rovine. Divadlo má oproti iným umeniam výhodu priamej komunikácie s divákom. Neraz využíva prvky interaktivity, obecenstvo vt̉ahuje do diania alebo rozširuje priestor hry do priestoru publika. Experimentálne interaktívne formy včleňujúce publikum priamo do divadelnej inscenácie sú dnes už pomerne bežné. Divadlo sa tak stáva hrou, a to nielen pre hercov, ale aj pre diváka, ktorý sa na nej musí aktívne zúčastnit. Podobný proces prebieha aj pri naratívnych videohrách. Dokonca i vtedy, ked' sú vystavané okolo konkrétnej postavy, či ked’ pripomínajú skôr interaktívne filmy, je nutný priamy vklad recipienta a jasná komunikácia s ním, aby sa inscenované videoherné konflikty mohli uskutočnit'. Podobne je na tom divák, ktorý sa ocitá v nejakej forme interaktívneho divadla - je síce situovaný do priestoru, v ktorom už existujú vopred dané rekvizity, postavy a pravidlá, avšak celý proces inscenácie ovplyvňuje svojou improvizáciou i svojou prítomnostou.

Paralela je zrejmejšia, ked’ si uvedomíme, že pri mnohých hrách využívajú programátori tzv. scripty. Ide o prvky programu, ktoré sa spustia iba vtedy, ak sa splnia vopred dané podmienky. Postavy videohry čakajú, často schované mimo dohl'adu hráča, za stenou, textúrou (dalo by sa povedat', oponou), dokial' hráč nevykoná konkrétne akcie alebo nezvolí konkrétne repliky. Až potom postavy hry reagujú a vstupujú na scénu, podobne ako herci v divadle, ktorí čakajú na správny podnet, aby mohli zahrat' svoju úlohu.

Inscenovanie $\mathrm{v}$ kontextoch hrania sa teda dá chápat ako variácia na proces simulovania. Zásadným prvkom, ktorý túto variáciu vytvára, je práve prítomnost̉ dramatického konfliktu. Konflikty sú nevyhnutnou súčastou hier či videohier. Dávajú hraniu ciel', bez nich by hráč nevedel, ako hra funguje. Konfliktné situácie môžu pozostávat’ z prekonávania doslovného konfliktu, ked’ má hráč poraził’ súpera, alebo môžu mat' dramatický charakter, ked' hráč musí vyriešit konflikt (príp. sériu konfliktov) typický pre naratívne štruktúry. Keby sme teda chceli vytvorit teoretickú štruktúru klasifikácie videohier na základe existujúcich umenovedných systémov, takéto delenie by

\footnotetext{
${ }^{17}$ Protikladom je film, ktorý, ak je spustený, sa odohráva bez toho, aby potreboval byt aktívne sledovaný. Divák filmu sa navyše do neho nemôže zapojit'.

${ }^{18}$ Porov. BENDOVÁ, H. Umění počítačových her. Praha : Akademie múzických umění, 2017, s. 218 - 220.
} 
mohlo vychádzat’ z delenia na základe formy konfliktných situácií. Základná dualita tohto delenia by bola postavená práve na kompetitívnych konfliktoch (hranie proti niečomu) a inscenovaných naratívnych konfliktoch (hranie sa na niečo; hranie odkrývajúce príbeh, rozpletajúce dramatickú zápletku). Toto delenie však nemožno chápat' ako prísne opozitné. Skôr má podobu škály, pričom umiestnenie konkrétnej videohry závisí od spôsobu, akým ju hráč má hrat. Dualistický charakter tohto prístupu vychádza z dualistického jadra Mikovej výrazovej sústavy ${ }^{19}, \mathrm{v}$ ktorom sú proti sebe postavené dva základné módy komunikácie, operatívny a ikonický. ${ }^{20}$

Podobne, ako sa oba komunikačné princípy vyskytujú v rozdielnej miere v textoch, tak ich môžeme $\mathrm{v}$ rôznej miere aplikovat' na videohry, pričom ich chápeme ako druh komunikácie. Konkrétnejšie vychádzame z modelu poetiky videohier estetika Mariána Kluvanca, ktorý bol navrhnutý v jeho dizertačnej práci. Kluvanec sa opiera o Mikovu výrazovú sústavu, pričom identifikuje dve základné polohy videohier - videoherné mechanizmy a estetické kvality videohier. Znázornil to nasledujúcou schémou:

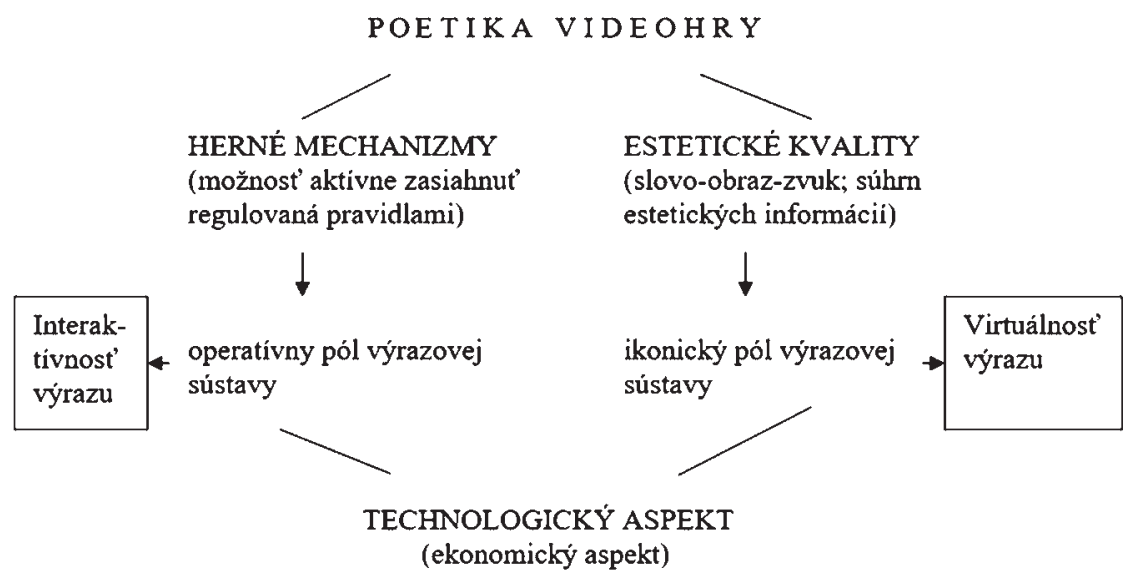

Toto je základný kl’uč k deleniu videohier, ktoré poslúži tomuto textu² ${ }^{21}$ Mikov prístup ku komunikácií a Kluvancova schéma poetiky videohier sú výsledkom myšlienkovej školy, ktorá je autorovi tejto štúdie bližšia a určuje metodológiu predkladanej štúdie. ${ }^{22}$

${ }^{19}$ Mikova výrazová sústava je schéma znázorňujúca výrazové prvky komunikácie, ktoré delí na dve základné skupiny: skupinu výrazových a poetických prvkov zameraných na operatívnu komunikáciu (administratívne texty, príkazy, návody a pod.) a ikonickú komunikáciu (hovorový štýl, umelecké texty a pod.). hrách.

${ }^{20}$ Operatívna komunikácia prevláda v kompetitívnych hrách, ikonická komunikácia v naratívnych

${ }^{21}$ Pripomíname, že hlavným cielom tohto textu nie je vytvorit funkčné akademické delenie videohier, ale poukázat’ na podobnosti medzi inscenačnými postupmi v divadelných a videoherných naráciach.

${ }^{22}$ Napr. teoretické delenie hier sa vzt’ahuje väčšinou na hry v ontologickej realite, ale pri videohrách môže zlyhat'. Súčasne existujú aj nové modely, ktoré delia hry podla ich ciel'u. Napríklad tzv. Threefold Model, ktorý je postavený na tom, že hráči očakávajú od hrania tri rozdielne prístupy (dramatický, simuláciu a zápolenie s hernými mechanikami), sa môže javit’ ako najlepší na triedenie videohier. Tento model však bol vytvorený ako pomôcka pri tvorbe špecifického druhu hier - RPG. Videohry majú omnoho širšie 
Väčšina videohier sa na škále ocitne uprostred (napr. StarCraft). ${ }^{23} \mathrm{Ak}$ v nich však prevláda väčšia miera naratívnych prvkov a ikonickej komunikácie, ide o hry, ktoré využívajú inscenačné postupy, aby simulovali dramatické konflikty. Tento klúč na triedenie videohier sme teda vytvorili pre potreby oddelenia tých videohier, ktoré využívajú podobný typ komunikácie ako divadlo, t. j. komunikácie priamej, vyžadujúcej si hráčovo zapojenie a jeho improvizačný vklad ${ }^{24}$ (podobne ako experimentálne a interaktívne formy divadla). Pokial' tento proces naozaj prebieha, mali by ho do istej miery vediet' reflektovat’ aj samotní hráči, respektíve, ich lexika a spôsob triedenia videohier by to mali naznačovat'.

Tu do našich úvah vstupuje druhá forma teoretickej reflexie videohier - forma, ktorá by sa dala chápat’ ako prúd myslenia „,zdola“. Zastupujú ho hráči, ktorých klasifikácia hier je pragmatická, vychádza zo skúsenosti s hraním a je tekutá - neustále sa mení podla toho, ako sa menia samotné videohry. Hráčmi používané pojmoslovie je teda nestále a nemá pevné hranice, hoci niektoré základné pojmy sú ustálené, napr. pojem adventúra, popisujúci dobrodružnú hru s príbehom, alebo už spomínané RPG - typ hier, kde hráč hrá v role hrdinu a na riešenie konfliktných situácií využíva matematické zákonitosti videohry. Práve tento prvok premenlivosti narúša spôsob vytvorenia pevnej odbornej reflexie a teórie videohier. Estetik Juraj Malíček o tom píše: „Akýkol'vek teoreticko-interpretačný vstup do sveta videohier sa musí vyrovnat’ s faktom, že neexistuje spoločný artikulačný slovník. Premýšl’anie a zárodky teórie o videohrách sú síce v rámci akéhosi slovníka, ale ten nie je dielom ich odt’ažitej teoretickej reflexie, má len spontánnu pragmatickú podobu.“ Malíček d’alej uvádza, že „mená druhov, žánrov a subžánrov videohier fungujú akoby bez systému, svojou vlastnou pragmatickou logikou. “25 Zároveň predkladá tézu, že o videohrách nie je v súčasnosti možné vypovedat' inak, iba z pohl'adu zainteresovaného pozorovatel'a, lebo pragmatická reflexia hier je premenlivá. Jediným aspektom, o ktorý sa teoretická reflexia videohier môže opierat', je podla neho interaktivita. Kladie ju na primárne miesto: hlavným účelom videohry je byt' interaktívna. Problém s teoretickou reflexiou videohier je teda postavený na tom, že na rozdiel od iných druhov umení sú videohry v prvom rade operatívnym druhom textov ${ }^{26}$, ikonická zložka stojí až na druhom mieste.

zameranie na spôsoby hrania. Práca s týmto modelom by si teda vyžadovala jeho preverenie aj pri iných herných princípoch (napr. pri stratégiách alebo tzv. striel'ačkách). Threefold Model navyše nekorešponduje s metodológiu tohto textu, hoci autor uznáva, že vhodne identifikuje všetky aspekty herných simulácií.

${ }^{23}$ Uvedomujeme si, že tento model triedenia videohier sa môže javit ako nedokonalý. Existujú videohry, ktoré sú v podstate len simuláciami bez očividného sútaživého či naratívneho aspektu (napr. The Sims). Avšak aj tieto simulácie sa dajú plnohodnotne umiestnit’ na našu škálu - hráč hrá „proti hre“. Takéto simulácie simulujú prekážky v podobe problémov, ktoré hráč musí zdolat', aby simulácia nad’alej bežala. Existujú tiež hry, ktoré v rovnakej miere obsahujú sútažnú aj naratívnu zložku. Skúsený hráč by pravdepodobne našiel niekol'ko príkladov, ktoré by bolo problematické priradit do k jednej z dvoch opozícií. Takéto hry by skončili pravdepodobne v strede. Ako sme však naznačili, ciel'om nie je vytvorit’ plne funkčnú teóriu klasifikácie hier, ale oddelit videohry s naratívom od ostatných videohier a zároveň ilustrovat' ich spoločné znaky s divadlom.

${ }^{24}$ Improvizácia tu nadobúda formu interakcie, pri ktorej má hráč k dispozícii isté pravidlá a obmedzenia hernými mechanikami či variáciami príbehu, avšak jeho postup videohrou je vol’ný. V rámci obmedzení a pravidiel sa správa slobodne a nakladá s nimi podl’a vlastného uváženia, nie podl'a vopred daného scenáru.

${ }^{25}$ MALÍČEK, J. Interaktivita vo videohrách. In INŠTITORISOVÁ, D. a kol. Divadlo - interaktivita, inscenovanost', diškurz, s. 295.

${ }^{26}$ Text je tu chápaný ako samostatná znaková sústava nesúca nejakú správu či ideu, ktorú môže recipient čítat’. 
Tento prístup však odporuje premenlivej hráčskej skúsenosti. Existujú hráči, ktorí dávajú prednost’ reflexii ikonickej zložky pred operatívnou. Zároveň existujú aj videohry, ktoré sú na tejto reflexii postavené, operatívna čast̉ je v nich sekundárna. Takým je napríklad spomínaný titul Life is Strange, ktorý nie je možno reflektovat inak než vo vztahu ikonickej zložke, lebo operatívna stránka hry je príliš jednoduchá a sama osebe nezaujímavá. Samotní hráči tento fenomén reflektujú. $\mathrm{V}$ ich slangu nejestvuje pre tento jav presné pomenovanie, ale hovorí sa o „multiplayerových hrách“ a "hrách s príbehom“. Multiplayerové hry sú hry pre viac hráčov súčasne, pričom v centre hrania je práve sútažný konflikt. Tento typ hier málokedy obsahuje naratívny prvok a ak aj je prítomný, mnohými hráčmi ostáva ignorovaný. Ked' však hráči hovoria o hrách s príbehom, majú na mysli na hry pre jedného hráča, v ktorých je vytvorený naratívny rámec. Subkultúra hráčov na nich oceňuje najmä možnost' vcítit’ sa do postáv a prítomnost' kvalitne prevedeného príbehu, ktorý je v harmónií s mechanizmami hrania. No tieto pojmy sú vel'mi vol'né, ich výskyt a spôsob, akým sa s nimi narába, indikuje práve prítomnost' dvoch spôsobov hrania videohier.

Je pritom zjavné, že tzv. príbehové videohry sú vyhl'adávané nielen pre ich interaktívne vlastnosti, ale predovšetkým pre imerzný zážitok vychádzajúci z participácie na naratívnom rozprávaní. Ide o podobný zážitok, aký dokáže priniest' divadlo, beletria či film. Avšak na tom, aby hráč daný zážitok docielil, nemajú podiel len tvorcovia videohry. Nezáleží iba na remeselnom prevedení hry, úrovniach, scenári, grafike či herných mechanizmoch. Na to, aby videohry fungovali ako naratívne médium, je nevyhnutná aj dobrovolná účast' hráča, a to nielen na úrovni aktívneho elementu hrajúceho hru a dodržiavajúceho pravidlá. Nestačí, aby ovládal postavu hry, musí byt' ochotný sa na hre podiel'at' aj na intelektuálnej a emocionálnej úrovni. Vyžaduje sa od neho istá miera empatie - podobne ako pri iných druhoch umenia narábajúcich s naratívnymi formami. Pri tomto procese reflexie sa popri interaktívnej a technickej stránke stávajú dôležitými aj iné aspekty videohier - hráči si všímajú aj ich estetické a umelecké kvality.

Tvorcovia videohier sú si vedomí prítomnosti tohto fenoménu, preto vzniklo niekol'ko hier, ktoré z neho priamo tažia. Jednou z nich je Frostpunk. Je to hra od pol'skej skupiny vývojárov 11 BIT STUDIO publikovaná v roku 2018. Ide o jednoduchú budovatel'skú stratégiu, v ktorej sa hráč pokúša udržat' pri živote a prípadne rozvíjat’ l’udskú kolóniu snažiacu sa prežit’ v nehostinných podmienkach za polárnym kruhom po globálnom ochladení. Z hl'adiska mechanizmov hrania je hra jednoduchá: v podstate stačí volit také možnosti výstavby, politiky a iných aspektov súvisiacich s fungovaním mesta, ktoré prinesú čo najpozitívnejšie výsledky. Príbehový rámec hry ju navyše robí pomerne lineárnou, ked’že hráč už po prvom hraní pozná jednotlivé prekážky a udalosti, ktoré musí zvládnut'. Avšak práve príbehová rovina Frostpunku je dôvodom, pre ktorý hra vznikla. Tvorcovia priamo vyzývajú hráča k emočnému zapojeniu. V príbehu je totiž ludstvo na pokraji vyhynutia a mesto, o ktoré sa hráč stará, je jedno z posledných, ktoré sa snaží prežit globálnu zimu. Problém však spočíva v tom, že najefektívnejšie riešenia sú často najmenej morálne, prípadne ambivalentné. Frostpunk tak stavia pred hráča dilemy, ktoré by sa hypoteticky mohli vyskytnút v hraničnej existenciálnej situácií načrtnutej naratívnym rámcom. Bez empatického zapojenia sa hra stáva nudnou, nezaujímavou a príliš jednoduchou. Emočná zainteresovanost' však z nej robí náročnú, híbavú hru, ktorá predstavuje pre hráča výzvu a konfrontuje 
ho s vlastným svetonázorom či schopnostou zvládat’ náročné situácie. Toto však funguje len $\mathrm{v}$ prípade, že hráč na tieto podmienky pristúpi.

Ďalším príkladom toho, ako intelektuálna a emočná participácia hráča buduje hru, je populárna multiplayerová hra World of Warcraft, ktorá s úpravami beží bez prestávky od roku 2004. Ide o RPG hru, kde hráči vytvárajú postavy, s ktorými potom preskúmavajú rozsiahly virtuálny svet. Môžu ich zapájat do fiktívnych konfliktov medzi frakciami, navštevovat’ jednotlivé lokácie sveta či riešit’ väčšie alebo menšie príbehové linky. World of Warcraft funguje ako simulácia fiktívneho sveta s vlastnými prebiehajúcimi dejinami. Jednotlivé naratívy prítomné v hre sa síce uzatvárajú a majú svoje vyvrcholenia, no celkový konflikt nebude pravdepodobne nikdy vyriešený. Jednotlivé lokácie navyše nepodliehajú lineárnemu času. Hráč tak môže absolvovat' udalosti, ktoré boli do hry umiestnené pri jej vzniku, aj najnovšie zápletky. V jednej lokalite môže stretnút postavu, ktorá je v inej lokalite mŕtva, prípadne byt̉ svedkom scény jej smrti. Tento časový paradox však narúša prirodzenú imerziu i naratív, ktorý svet World of Warcraft obsahuje. Samozrejme, hráč ho môže ignorovat’ a zamerat’ sa na kompetitívny aspekt hry - hrat’ ju výlučne ako sadu výziev či stretnutí na bojiskách s inými hráčmi. Ak sa však rozhodne vstupovat’ do zinscenovaných naratívov, musí sa zapojit nielen emočne, ale tiež intelektuálne, aby si zvolil taký postup, ktorý mu sprostredkuje čo najlineárnejšie zobrazenie jednotlivých udalostí, prípadne si tieto udalosti musí zoradit' do správneho poradia vo svojom vedomí. Tvorcovia hry rátali s oboma variantmi hrania, ktoré si navzájom neprekážajú ani neodporujú. Inscenačný charakter naratívu je o to výraznejší, že nie vždy je v hre priamo prítomný. Hráč musí splnit určité podmienky, aby sa daná udalost’ spustila. Ak sa v udalosti i nechtiac ocitne, môže ju jednoducho ignorovat’ alebo priamo vypnút. Tým jednotlivé dejinné udalosti Word of Warcraft nadobúdajú takmer až divadelný charakter, ked’že sa hra snaží o imerziu a zároveň obsahuje scudzujúce prvky. Hráč je nielen recipientom, ale aj postavou, hercom v hre: fungovanie naratívu závisí od jeho rozhodnutia, ako a či vôbec bude za konkrétnu postavu hrat'.

Tento dvojitý aspekt zachytila aj Helena Bendová vo svojej knihe Umění počitačových her: „Nejenom, že je to podle mého soudu z narativního hlediska nepř́liš podařená fantasy sága, coby hráčka jsem tuto rovinu World of Warcraft jednoduše zcela vypustila. (...) Přesto jsem paradoxně schopna chápat WoW jako umění, i když dost možná kvưli aspektům, které jeho tvůrci původně nepovažovali za to, co z této hry bude činit kvalitní dílo. (...) Na této hře mne baví především tzv. raidovaní, tedy bojové výpravy s devíti až devětadvaceti dalšími lidmi, jejichž úspěch závisí na choreograficky přesném a dokonale zkoordinovaném zvládnutí několik minut trvajících, velmi obtížných soubojů. “ ${ }^{27}$ Bendová používa v akademickom texte netradične osobný prístup na to, aby ilustrovala nielen dvojitý prístup k hraniu, ale aj proces zvýznamňovania hry hráčom. Priznáva, že naratívna roztrieštenost’ robí príbeh hry pre ňu neatraktívnou, namiesto príbehu sa zameriava na mechanizmy hrania a sociologický aspekt hry. Zároveň sa jej príklad dá chápat’ ako popísanie stavu, v ktorom hra existuje v oboch rovinách - ako súboj s niečím i ako hranie sa na niečo.

Vklad hráča videohry a jeho ochota spolupracovat’ na interaktívnej fikcii ho stavia do pozície, v ktorej zastáva viacero úloh. Nie je len recipientom hry, ale aj spolutvor-

${ }^{27}$ BENDOVÁ, H. Umění počítačových her, s. 179 - 180. 
com výsledného diela, ktoré sa uskutočňuje až v jeho vedomí. Z prostriedkov, žánrových modelov, naratívnych prvkov, klišé a z možností, ktoré mu ponúknu tvorcovia hry, buduje vlastný zážitok: príbeh prispôsobuje vlastnému vkusovému a mentálnemu nastaveniu. Stáva sa tak i režisérom, scenáristom a zároveň hercom v hlavnej úlohe, pričom uskutočňuje fikciu niekoho iného. Inscenačný proces neprebieha priamo v našej ontologickej realite, na skutočnej scéne, ale vo virtuálnom priestore a zároveň vo vedomí hráča.

Uvedené však neplatí o všetkých hrách, ktorých mechanizmy sú rámcované rozprávaním či príbehom. Jednotlivé druhy a typy hier určujú aj spôsob, akým sa hry hrajú. Strategická hra môže pracovat’ s nejakým druhom naratívu, avšak hráč je postavený do roly „božského velitela“", ktorý na postavy v hre pozerá zvrchu. Takýto druh simulácie nepraje zaužívaným naratívnym formám. Na druhej strane existujú typy hier, ktoré sú tomuto princípu priamo prispôsobené. Ide o už spomínané adventúry, RPG hry (ktoré sú vyslovene postavené na tom, aby hráč hral nejakú rolu), prípadne o akčné hry. Aj ked' sa hráč musí vžit’ do vopred určenej postavy, interaktívny charakter videohier mu zaručí aspoň čiastkovú kontrolu nad priebehom naratívu. Vd’aka popísanému momentu sa tieto videohry podobajú tzv. larpovým hrám² ${ }^{28}$. Aj ony by sa dali chápat’ ako druh simulácie, avšak na to, aby mohli byṫ funkčné, využívajú inscenačné prostriedky a jazyk divadla. Hráč tak nie je len tým, kto sa hrá, ale zároveň aj hercom v improvizačnej inscenácií. ${ }^{29}$ Naratívne videohry inscenujú veci podobným spôsobom, len sú presunuté z ontologickej reality do virtuálneho priestoru a často sú určené iba jednému hráčovi. Larpové hry tým najlepšie ilustrujú spoločné znaky komunikácie videoherného média a divadla. ${ }^{30}$ Sú to hry prebiehajúce v simulovanej realite a zároveň špecifický druh interaktívneho divadla.

Práve pomenovania ako „RPG“ či „,adventúra“, ktoré sú samé osebe vel’mi fluidné31, poukazujú na to, že aj vratké pojmoslovie videohernej komunity cíti potrebu diferencovat' hry nielen na základe mechanizmov, ale aj na základe poskytovaného zážitku. Tento zážitok je v podstate podobný zážitku z hrania larpových hier.

Na predložených príkladoch sme ilustrovali, že hráči videohier sami pocitujú a reflektujú inscenačný či dokonca divadelný charakter niektorých videohier, pre ktoré vytvorili vlastné pojmy (RPG, adventúry). Avšak ani jeden z prístupov predstavených v tomto texte zatial' nepracuje s dostatočne zrozumitel’nými a výstižnými pojmami. Ak chceme využit už existujúce umenovedné slovníky, musíme zaužívané pojmy upravit’ a dat' ich do nových významových súvislostí. Využívanie lexiky hráčov zase vedie k nepresnosti, práve pre premenlivú podstatu ich klasifikácie. V oboch prípadoch, t. j. v umenovedných slovníkoch aj v slovníku hráčov, sa zaužíval po-

${ }^{28}$ Live Action Role Play - ide o formu hier, ktorá sa dajú vnímat’ aj ako uzavreté improvizované divadelné hry. Tvorcovia hry predstavujú nehráčske postavy, ktoré moderujú priebeh hry a rámcujú jej naratív, pričom využívajú skutočný priestor, rekvizity i kostýmy na vybudovanie čo najvernejšieho zážitku. Od hráčov sa vyžaduje rovnaký prístup, t. j. dokonalý ponor do rol, ktoré sa rozhodnú hrat', avšak dopredu nie sú oboznámení s celým priebehom naratívu. Pôžitok $\mathrm{z}$ hrania spočíva práve v dialogickej interakcii nehráčskych a hráčskych postáv a z odhal’ovania a usmerňovania naratívu samotnými hráčmi.

${ }^{29}$ Porov. BENDOVÁ, H. Umění počítačových her, s. 223.

${ }^{30}$ Videohry, hlavne RPG a adventúry, využívajú v podstate rovnaké divadelné procesy a princípy ako LARP-ové hry, len navyše musia zabezpečit komunikáciu medzi dvomi rovinami reality (ontologickou a virtuálnou).

${ }^{31}$ Prvé virtuálne RPG hry len pramálo dosahujú komplexnosta rôznorodost či inscenačné možnosti súčasných RPG videohier, teda tento pojem označuje príliš rôznorodú škálu hier. 
jem interaktívna fikcia, ktorý označuje videohry pracujúce s rôznymi formami naratívnych prvkov. Tým sa poukazuje tak na interaktívny charakter videohier, ako aj na ich fikčný charakter. Toto pomenovanie však nie je vhodné pre všetky videohry a naopak, pod interaktívnu fikciu môžu spadat aj larpové hry. Navyše, ak by sme $\mathrm{z}$ tohto pojmu chceli spravit’ súčast' uceleného systému videohier, narazili by sme na to, že chýba pomenovanie opozície, ktoré by popisovalo videohry postavené na kompetitívnosti. Ako najvýstižnejší pojem na popísanie tejto skupiny videohier teda navrhujeme označenie "naračné videohry“, pričom princíp, na základe ktorého ich môžeme dištancovat’ od kompetitívnych videohier, by mohol byt’ postavený na miere využitia inscenačných prostriedkov. Také videohry fungujú na rovnakých princípoch ako divadelné inscenácie, no s tým rozdielom, že ich komunikácia prebieha medzi virtuálnou a ontologickou realitou - využívajú teda aj výrazové prostriedky filmu (či literatúry).

\section{Záver}

V štúdií sme sa pokúsili dokázat', že inscenácia v kontexte videohier je procesom, ktorý vytvára interaktívnu simuláciu s naračnými prvkami. Konštruovanie foriem narácie (či už príbehu alebo len vol’ného rozprávania) používa podobné postupy, aké nájdeme v divadelných inscenáciách. Do videohernej simulácie sa vnáša dramatický konflikt, herecké stvárnenia, scénická hudba, buduje sa virtuálna scéna. Hráč do nej vstupuje ako recipient, ale zároveň aj ako aktívny, hybný element. Hru hrá nielen na úrovni spúštača simulácie, ale aj na úrovni spoluautorskej. Súčastami tohto procesu sú improvizačný princíp (nemusí sa riadit pevným scenárom), herecká zložka (od hráča sa vyžaduje, aby hral nejakú rolu) a emočný vklad. Mohli by sme povedat', že videohry s naráciou, zvlášt RPG a adventúry, sú v skutočnosti virtuálnym divadlom pre hráčov. Toto tvrdenie sa pritom dá opriet nielen o teoretickú reflexiu videohier, ale tiež o hráčsku skúsenost'.

V súčasnosti sledujeme vo svete videohier novú vlnu záujmu o tzv. virtuálnu realitu. Hranie prostredníctvom nových druhov ovládačov a herných periférií už vyžaduje nielen recepčné a mentálne, ale aj pohybové zapojenie hráča, čím sa herecký aspekt hrania ešte posilňuje. Stále síce nie je (a pravdepodobne ani nikdy nebude) na úrovni pravého herectva, ale paralely sú zrejmejšie. Vd’aka týmto princípom môžeme odkryt’ tú čast’ videoherného sveta, ktorá by mohla mat’ potenciál dostat’ sa na rovnocennú úroveň s inými dramatickými umeniami, ked’že prináša omnoho interaktívnejší a premenlivejší zážitok než divadlo či film. Zároveň sa otvára priestor pre uvažovanie nad tým, ako by sa dali využit možnosti inscenačných simulácií v prospech tradičnejšieho umeleckého prejavu. Jedným z takých pokusov je interaktívna hra ${ }^{32}$ Premena, ktorú do svojich priestorov umiestnil Goetheho inštitút v Bratislave. Recipient sa vd’aka virtuálnej realite ocitá v priestore z Kafkovho príbehu Premena, čím sa mu má sprostredkovat interaktívny, živý a subjektívny zážitok z literárneho diela. ${ }^{33}$ Nie je ambíciou nášho textu hodnotit’ toto prevedenie, ale dá sa konštatovat', že ide o ilustráciu toho, kam sa videohry môžu uberat' - byt’ interaktívnymi simulá-

${ }^{32}$ Hoci pojem hra je tu využitý pomerne nepresne, ked’že táto virtuálna inscenácia je v porovnaní s inými videohrami málo interaktívna. O inscenáciu však nepochybne ide.

${ }^{33}$ Porov. ČABÁK, M. Virtuálna premena Kafkovej premeny. In Knižná revue, 2018, roč. 28, č. 11, s. 17. 
ciami tradičného umenia. Zatial' simulujú predovšetkým populárne žánre literatúry a filmu (fantasy, sci-fi, horor, vojnové príbehy a pod.). Ide však o mladé, rýchlo sa meniace umenie, ktorého jazyk a semiotické pole sa ešte formujú, pričom jeho potenciál je obrovský. ${ }^{34}$

\section{INTERACTIVITY AND PRODUCTION WORLDS \\ (Emphasizing Simulation and Production Issues in the Videogames)}

\section{Juraj BÚRY}

The text implicitly compares the principles of the production, especially the theatrical, with the principles of creating a narrative conflict in video games. It explicitly focuses on the processes of video game simulation. It's carried out through the optics of two approaches to video game theory. The first is the aspect of professional discourse in which it uses already established professional terminology from theatrical theory and tries to identify aspects of video games that correspond with it. In doing so, the author of the text suggests that there are two basic video-game principles competitiveness and interactive narration. Those principles oppose each other while focusing on the second. So the author understands the production as a kind of simulation and argues why this storytelling principle also appears in video games. The second principle of thinking about video games is thinking from the perspective of the players. In this context, the author seeks arguments to confirm his thesis. In the unstable terminology of video games, he reveals basic thinking in opposition to competitive playing and role-playing. Ultimately, he describes the relationship between the production and simulation in the context of video games as a narrative medium.

Text vznikol v rámci doktorandského štúdia na Ústave literárnej a umeleckej komunikácie Univerzity Konštantína Filozofa v Nitre, školitel' Juraj Malíček.

\section{LITERATÚRA}

BENDOVÁ, Helena. Umění počítačových her. Praha : NAMU, 2016. 354 s. ISBN 978-80-7331-421-7.

ČABÁK, Marek. Virtuálna premena Kafkovej premeny. In Knižná revue, 2018, roč. 28, č. 11, s. 17. ISSN 1210-1982.

INŠTITORISOVÁ, Dagmar a kol. Divadlo - interaktivita, inscenovanost', diškurz. Nitra : Univerzita Konštantína Filozofa, Filozofická fakulta, Ústav literárnej a umeleckej komunikácie, 2013. 504 s. ISBN 978-80-8094-434-6.

KLUVANEC, Marián. Estetická reflexia interaktívnej fikcie. [Dizertačná práca]. Nitra : Univerzita Konštantína Filozofa, Filozofická fakulta, Ústav literárnej a umeleckej komunikácie, 2008. $160 \mathrm{~s}$.

MALÍČEK, Juraj. Popkultúra: Návod na použitie. Nitra : Univerzita Konštantína Filozofa, Filozofická fakulta, Ústav literárnej a umeleckej komunikácie, 2012. 192 s. ISBN 978-80-558-0204-6.

${ }^{34}$ Za pomoc a vedenie pri príprave tohto textu autor d’akuje docentke Michaele Malíčkovej. 
MALÍČKOVÁ, Michaela. Hra(nie) len ako estetický fenomén. Nitra : Univerzita Konštantína Filozofa, Filozofická fakulta, Ústav literárnej a umeleckej komunikácie, 2008. 150 s. ISBN 97880-8094-430-8.

MELISSINOS, Chris - O'ROURKE, Patrick. The Art of Video Games. New York : Rizzoli US, 2012. ISBN 9781599621104.

PLESNÍK, Lubomír a kol. Tezaurus estetických a výrazových kvalít. Nitra : Ústav literárnej a umeleckej komunikácie, 2008. 474 s. ISBN 978-80-8094-350-9.

Juraj Búry

Ústav literárnej a umeleckej komunikácie

Filozofická fakulta

Univerzita Konštantína Filozofa v Nitre

Štefánikova 67

94974 Nitra

e-mail: jurajbury@gmail.com 